\title{
Classificação da Organização Mundial de Saúde para as neoplasias dos tecidos hematopoiético e linfóide: proposta de padronização terminológica em língua portuguesa do grupo de hematopatologia da Sociedade Brasileira de Patologia
}

\author{
World Health Organization Classification of Haematopoietic and Lymphoid Tissues Tumors: a proposal for the Portuguese \\ language terminology standardization from the hematopathology group of the Brazilian Society of Pathology
}

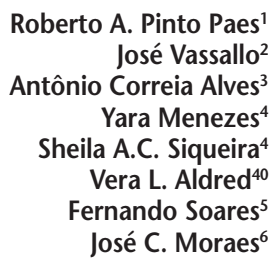

Novos conhecimentos da biologia dos processos linfoproliferativos, como conseqüência de estudos multidisciplinares, imunológicos, moleculares e genéticos, associados à melhor compreensão da clínica e ao quadro morfológico, permitiram, nos últimos anos, grande avanço no entendimento da natureza destes processos, contribuindo muito para uma classificação das entidades clinicopatológicas.

Esta classificação deveria incluir entidades clinicamente relevantes, associando-se o comportamento clínico com características morfológicas e imunogenéticas.

Em 1994, um grupo de patologistas autodenominado International Lymphoma Study Group propôs uma nova classificação das neoplasias linfóides (1). Consistia em uma lista de entidades clinicopatológicas reconhecidas e obedecia quase sempre à terminologia existente. Baseava-se, portanto, em entidades reais definidas por uma combinação de aspectos morfológicos, imunofenotípicos, genéticos e clínicos. Os autores batizaram-na com o nome de Real (Revised European-American Classification of Lymphoid Neoplasms). Estas neoplasias estão divididas em três categorias principais: neoplasias de células $B$, neoplasias de células $T$ e NK e linfoma de Hodgkin.
A classificação da Organização Mundial de Saúde (OMS), publicada em 2001 (2), para os tumores dos tecidos linfóides e hematopoiéticos, é fruto de um projeto colaborativo entre a European Association for Haematopathology e a American Society for Haematopathology. Após o lançamento da Real a pedido da OMS, em 1995, foi formada uma comissão com membros de ambas as sociedades, que propôs uma lista consensual de neoplasias mielóides, linfóides e histiocíticas, com descrições dos principais aspectos histológicos e imunológicos e critérios para diagnóstico. A classificação da OMS está baseada nos princípios definidos pela Revised European-American Classification of Lymphoid Neoplasms, com algumas modificações incorporadas para atualizá-la, estendendo-se os mesmos princípios para a construção e expansão da classificação, incluindo também as neoplasias mielóides, histiocíticas e mastocíticas (2).

A classificação da OMS/2001 baseia-se em critérios morfológicos e imunoistoquímicos bem difundidos entre nós e comprovadamente associados a elevada concordância interobservadores, havendo também forte fundamentação biológica, incluindo-se as mais atuais evidências da genética molecular e, em especial, marcada utilidade clínica (3).

\section{Referências}

I. Harris, N.L. et al.A revised European-American classification of lymphoid neoplasms: a proposal from the International Lymphoma Study Group. Blood, 84: I 361-92, 1994.

2. Jaffe, E.S. et al. (Ed.) World Health Organization classification of tumours: pathology and genetics of tumours of haematopoietic and lymphoid tissues. Lyon: IARC Press, 200I.
3. Harris, N.L. et al. (1999) The World Health Organization classification of neoplastic diseases of the hematopoietic and lymphoid tissues: report of the Clinical Advisory Commitee Meeting, Airlie House, Virginia, November, 1997. Annals of Oncology, 10: 141932,1997

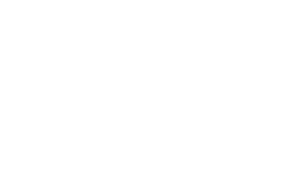




\section{Anexo}

\section{Classificação da OMS para neoplasias dos tecidos linfóide e hematopoiético (2001)}

\section{Doenças mieloproliferativas crônicas}

- Leucemia mielóide crônica

- Leucemia neutrofílica crônica

- Leucemia eosinofílica crônica/síndrome hipereosinofílica

- Policitemia vera

- Mielofibrose idiopática crônica

- Trombocitemia essencial

- Doença mieloproliferativa crônica, inclassificável

Doenças mielodisplásicas/mieloproliferativas

- Leucemia mielomonocítica crônica (LMMC)

- Leucemia mielóide crônica atípica

- Leucemia mielomonocítica juvenil

- Doença mielodisplásica/mieloproliferativa inclassificável

Síndromes mielodisplásicas

- Anemia refratária

- Anemia refratária com sideroblastos em anel

- Citopenia refratária com displasia multilinear

- Anemia refratária com excesso de blastos

- Síndrome mielodisplásica associada com anormalidade cromossômica isolada del $(5 q)$

- Síndrome mielodisplásica inclassificável

Leucemia mielóide aguda, SOE

- Leucemia mielóide aguda minimamente diferenciada

- Leucemia mielóide aguda sem maturação

- Leucemia mielóide aguda com maturação

- Leucemia mielomonocítica aguda

- Leucemias monoblástica e monocítica agudas

- Leucemia eritróide aguda

- Leucemia megacarioblástica aguda

- Leucemia basofílica aguda

- Pan-mielose aguda com mielofibrose

- Sarcoma mielóide

Leucemia aguda de linhagem ambígua

- Leucemias mielóides agudas (LMA)

- LMA com anomalias citogenéticas recorrentes
- $\quad$ LMA com t $(8 ; 21)$ ( q 22; q 22), (LMA1/ETO)

- LMA com inv (16) (p 13 q 22) ou t $(16 ; 16)$ (p 13; q 22), (CBFb/MYH11)

- Leucemia promielocítica aguda (LMA com t $(15 ; 17)$ (q 22; q 12), PML/RAR $\mu$ )

- LMA com anomalias (11 q 23) (MLL)

- LMA com displasia multilinear

- Com síndrome mielodisplásica pregressa

- Sem síndrome mielodisplásica pregressa

- LMA e SMD relacionadas à terapêutica

- Relacionada a agentes alquilantes

- Relacionada ao inibidor da topoisomerase II

Neoplasias de células linfóides $B$

- Neoplasias de células B precursoras

- Linfoma/leucemia linfoblástica de precursor B

- Neoplasias de células B maduras

- Leucemia linfocítica crônica/linfoma linfocítico

- Leucemia prolinfocítica B

- Linfoma linfoplasmocítico

- Linfoma da zona marginal esplênica

- Tricoleucemia

- Mieloma múltiplo

$\left.\begin{array}{l}\text { - Plasmocitoma ósseo } \\ \text { - Plasmocitoma extra-ósseo }\end{array}\right\} \begin{aligned} & \text { Neoplasias de } \\ & \text { plasmócitos }\end{aligned}$

- Linfoma da zona marginal extralinfonodal do tecido linfóide associado à mucosa (linfoma Malt)

- Linfoma da zona marginal linfonodal

- Linfoma folicular

- Linfoma de células do manto

- Linfoma difuso de grandes células B

- Linfoma de grandes células B mediastinal (tímico)

- Linfoma de grandes células B intravascular

- Linfoma primário de efusões

- Linfoma/leucemia de Burkitt

- Proliferações de células B de potencial maligno incerto

- Granulomatose linfomatóide

- Doença linfoproliferativa pós-transplante 


\section{Neoplasia de células linfóides T e NK}

- Neoplasias de células T precursoras

- Linfoma/leucemia linfoblástica de precursor T

- Linfoma de células NK blásticas

- Neoplasias de células T e NK maduras

- Leucemia prolinfocítica T

- Leucemia linfocítica de grandes células T granulares

- Leucemia agressiva de células NK

- Leucemia/linfoma de células T do adulto (HTLV1 +)

- Linfoma de células NK/T extranodal, do tipo nasal

- Linfoma de células T do tipo enteropatia

- Linfoma de células T hepatoesplênico

- Linfoma cutâneo de células T, do tipo paniculite subcutânea

- Micose fungóide

- Síndrome de Sézary

- Linfoma cutâneo primário de grandes células anaplásicas

- Linfoma de células T periféricas não-especificado

- Linfoma de células T angioimunoblástico

- Linfoma de grandes células anaplásicas

- Proliferações de células T de potencial maligno incerto

- Papulose linfomatóide

\section{Linfoma de Hodgkin}

- Linfoma de Hodgkin, predominância linfocítica nodular
- Linfoma de Hodgkin clássico

- Linfoma de Hodgkin clássico, esclerose nodular

- Linfoma de Hodgkin clássico, rico em linfócitos

- Linfoma de Hodgkin clássico, celularidade mista

- Linfoma de Hodgkin clássico, depleção linfocítica

\section{Neoplasias de células histiocíticas e dendríticas}

- Neoplasias de células macrofágicas/histiocíticas

- Sarcoma histiocítico

- Neoplasias de células dendríticas

- Histiocitose de células de Langerhans

- Sarcoma de células de Langerhans

- Sarcoma/tumor de células dendríticas interdigitantes

- Sarcoma/tumor de células dendríticas foliculares

- Sarcoma de células dendríticas sem outra especificação

\section{Mastocitose}

- Mastocitose cutânea

- Mastocitose sistêmica indolente

- Mastocitose sistêmica associada com doença hematológica clonal de linhagem não-mastocítica

- Mastocitose sistêmica agressiva

- Leucemia mastocítica

- Sarcoma mastocítico

- Mastocitoma extracutâneo 